\title{
Digital Da'wah Communications for The Prosperous Justice Party During The Covid-19 Pandemic
}

\author{
Khoiruddin Muchtar $^{1 *} \&$ Marlida Maulidawati ${ }^{2}$ \\ ${ }^{12}$ UIN Sunan Gunung Djati Bandung \\ *email.khoiruddin@uinsgd.ac.id
}

\begin{abstract}
This study aims to identify da'wah messages on the TikTok@pksejabtera account during the Covid-19 pandemic related to denotative, connotative, and mythical meanings in da'wah content on the TikTok@pksejabtera account limited to tausyiah content from da'i to mad'u with the hashtag \#tausyiah, \#habib, \#Islam, \#pkespelayanrakyat, \#remembrance, \#PKS, \#Bertualangrasa, \#tausyiahislam, \#minitausyiah, \#tausyiabhabibsalim, \#ramadhan2021, and \#syekhalijaber. This study uses a semiotic analysis method with a qualitative approach. The results showed that denotative Meaning could be observed from the choice of words and the arrangement of sentences in the text; connotative Meaning can be observed from the video images displayed in each scene. In contrast, the Meaning of myth can be found in the da'wah content on the TikTok@pksejahtera account by observing the preacher when delivering tausyiah.
\end{abstract}

Keywords: semiotic analysis, TikTok account, digital da'wah, da'wah message

\begin{abstract}
ABSTRAK
Penelitian ini bertujuan untuk mengidentifikasi pesan dakwah pada akun TikTok (a)pkejahtera selama pandemi Covid-19 terkait dengan makna denotatif, konotatif, dan mitos dalam Konten dakwah pada akun TikTok@pksejahtera dibatasi pada konten tausyiah dari da'i kepada mad'u dengan tagar \#tausyiah, \#habib, \#Islam, \#pkspelayanrakyat, \#zikir, \#PKS, \#Bertualangrasa, \#tausyiahislam, \#minitausyiah, \#tausyiahhabibsalim, \#ramadhan2021, dan \#syekhalijaber. Penelitian ini menggunakan metode analisis semiotika dengan pendekatan kualitatif. Hasil penelitian menunjukan bahwa, makna denotatif dapat diamati dari pemilihan kata dan penyusunan kalimat dalam teks, makna konotatif dapat diamati dari gambar video yang ditampilkan dalam tiap adegan, sedangkan makna mitos dapat ditemukan dalam konten dakwah pada akun TikTok @pksejahtera dengan mengamati da'i saat menyampaikan tausyiah.
\end{abstract}

Kata kunci : analisis semiotika, akun Tik'Tok, dakwah digital, pesan dakwah 


\section{INTRODUCTION}

At the end of 2019, the world was shocked by the emergence of a variant of the Sars virus known as the coronavirus, which first appeared in Wuhan, China, China. The rapid spread of this virus has caused outbreaks throughout the country. In the end, the WHO, as a world health organization, decided that this corona outbreak included the Covid-19 pandemic, namely an epidemic of coronavirus disease that spreads in almost the whole world. Early March 2020, this pandemic began to be detected, appearing in Indonesian territory, especially in the city of Depok. The spread of Covid-19 began with two Depok residents, which expanded until June 22, 2021, the number of infected reached 1,900,000 cases with 1,790,000 recovered, and 54,622 died.

Covid-19, which is increasingly widespread throughout Indonesia, has resulted in several activities that can cause crowds to be banned, including da'wah activities in the form of tabligh gathering the honey in one place. The tabligh activities of the da'i in conveying messages of truth, justice, and goodness also encountered obstacles, while tabligh was a business system that needed to be continuously carried out to broadcast and communicate Islam so that individuals would embrace it or collectively both through writing and orally (Achmad, 1985: 2-3)

During the pandemic, the Prosperous Justice Party, as a party that claims to be a da'wah party, carried out da'wah by digital means. PKS is one of the political parties in Indonesia. PKS introduced its party as a political party based on Islam and as a da'wah organization following the articles of association of PKS Chapter 1 Article 2 concerning Principles. Even in Chapter 1, Article 3 relating to Principles, paragraphs 1 to 3 state that PKS is a party characterized by noble, innovative, patriotic, and service-minded character and professional.

Da'wah is a form of PKS responsibility to create a civil society that establishes the principle of humanizing humans and involves them as a whole in the message of da'wah, regardless of their background; an invitation to spread a culture of safe and peaceful living; strengthening the attitude of social solidarity and strengthening the spirit of friendship and realizing a complete human being by maintaining closeness to Allah SWT. The realization of the PKS target from a cadre party to become a solid mass-based cadre party in order to empower the majority component of the Indonesian nation, namely women, the younger generation, farmers, 
laborers, fishers, and traders.

The values promoted by PKS as a da'wah party make PKS da'wah challenged to keep up with the times by the concept of al Islamu sholih likulli era wa eating (Islam according to the conditions of time and place). Moreover, one of the target segments of PKS to become constituents is the younger generation, so digital da'wah is a solution taken by PKS during the pandemic to spread the values of justice, truth, and kindness. Da'wah is an activity to invite or call towards Allah's guidance or the way of Allah. The method of Allah (sabillillah) contains the Meaning of absolute truth (al-haqq), justice (al-'adl), and general good (al-maslahah al-ammah). Da'wah is an activity that invites mad'u both in writing, behavior and so on. Da'wah activities are carried out consciously and planned to influence mad'u, both individually and in groups. So that there arises in mad'u an understanding, awareness, appreciation attitude, and practice of religious teachings as a message conveyed to him without any element of coercion (Arifin, 2015: 8-9). Digital da'wah is an activity of invitation to the way of Allah, which is carried out in a planned manner using digital media to convey da'wah messages. Digital media referred to here is new media, namely the terminology to explain the convergence between computerized digital communication technology and connection to the network. The term new media emerged because of the internet, where the media currently using the internet network. New media is a communication technology that allows for interactivity between users and between users and information. When it comes to today's media, interactivity is a characteristic of most media, especially those that operate online. (William, Rice, Rogers. 1988: 3) Digital da'wah carried out by PKS uses new media, including social media categories, namely Twitter, Facebook, YouTube, Instagram, and even TikTok. Social media is a new media used to carry out social interactions to stay connected and share information in writing, images, or videos via the internet network. Therefore, researchers are interested in seeing how the content of PKS propaganda messages during the pandemic through TikTok accounts according to semiotic analysis.

Research on the Da'wah of the Prosperous Justice Party has been carried out, including research conducted by First, Sahabat Ujang, Zaenal Mukarom, Dewi Sadiah (2018), "Planning the Da'wah of Islamic Political Parties," the study discusses the Planning of the PKS Party as a political organization in carrying Islam as an orientation. Politics that is of particular concern to PKS cadres. The PKS Party made the plan to work meetings of 
cadres and administrators of the West Java PKS DPW. Second, Nur Wahid (2019), "The Prosperous Justice Party's (PKS) Da'wah Trail Enters Muhammadyah: Observing the Case in Yogyakarta as a Political Phenomenon of Da'wah," study discusses the political-religious aspect, PKS propaganda that penetrated Muhammadiyah's house, which is a manifestation of the existence of PKS as a political party with da'wah wings. Thus, politics and religious da'wah go hand in hand. Third, Arum Marina Sari (2019) "The Prosperous Justice Party (PKS) Da'wah Strategy in Improving the Quality of Life of People in Metro City" study discusses PKS, which has a da'wah strategy that is used to improve the quality of life of PKS cadres in Metro City, especially in 15 A Iringmulyo Metro Timur. The da'wah strategy used by PKS is a sentimental strategy (al-manhaj ala'thifi) which gives da'wah partners impressive advice and provides services, namely the Pos Eka program or the Family Empowerment Post. This study aims to discover and explain the denotative, connotative, and mythical meanings of da'wah messages in the@pksejahtera TikTok account content. The research method used is a qualitative method with a semiotic analysis approach, Roland Barthes' semiotic analysis technique. This research is qualitative research with a descriptive paradigm where the researcher tries to describe the results of observations on the object of study. Semiotic analysis can be described as an analysis that can determine how denotative, connotative, and mythical meanings are in messages. The data in this study are qualitative in the form of words, sentences, and narratives related to categorization, characteristics in the form of questions, or comments. To collect data related to this research, the researcher traced da'wah content containing messages of justice, truth, and goodness in Allah's way on TikTok accounts. The data collected is in news articles, photos uploaded by reports, and screen capture results from uploads.

\section{RESULT AND DISCUSSION}

Digital da'wah carried out by PKS uses new media, including social media categories, namely Twitter, Facebook, YouTube, Instagram, and even TikTok. Social media is a new media used to carry out social interactions to stay connected and share information in writing, images, or videos via the internet network. TikTok is one of the most popular social media in Indonesia. Based on the Priori Data report, there is an increase in the number of Tik'Tok users via android and IOS in Indonesia, reaching 30.7 million people as of July 2020. The mobile application market research 
company App Annie released the latest report on the mobile application landscape in the first quarter of 202. TikTok is a short video-based social media won the title as the application with the highest number of downloads beating Facebook, Instagram, and WhatsApp.

Tik'Tok is a popular app during the pandemic. Angga Anugrah Putra conveyed to Tik'Tok Indonesia's Head of Content and User Operations that this application was widely downloaded during the corona pandemic (covid-19). The number of users increased by 20 percent when compared to standard times. The majority of users create educational content, food to fashion in the application. Educational content is the type of content that has experienced the most increase during the pandemic. TikTok has become a viral social media during the pandemic because it is easy to use, does not require many resources, and has various features. The advantages of this application make users have more freedom to find exciting accounts as needed and then follow each upload of the report to interact via DM and continue to provide support and commentary that is the culture of Zoomer (Gen-Z). The target and segmentation of users of this application are Gen$Z$ aged $13-24$ years, where this generation was born when the world was digitally connected.

Da'wah content is displayed on the TikTok@pksejahtera account, where these contents contain messages of aqidah, sharia, and morals. The TikTok account@pksejahtera is the official TikTok account of the Prosperous Justice Party. This account already has 21,6000 followers. The posted content has various themes ranging from political, social, cultural, and economic issues to related information about the Prosperous Justice Party. From the many videos posted by @ pksejahtera, researchers examined the content that conveys the message of da'wah. Da'wah messages on the TikTok account@pksejahtera are more focused on tausyaih content from preachers to mad'u (Tik'Tokers).

Da'wah content on the TikTok account@pksejahtera only has nine ranges over nine months, from September 3, 2020, to June 22, 2021. The TikTok account@pksejahtera has posted about 174 videos. It turns out that the content with the most views is the content about PKS's attitude towards the BKN's national insight test that endangers the nation's future. It was broadcast 736,000 times, liked by 51,800 tiktokers, commented on by 4,810 tiktokers, and shared 7,882 times. The hashtags for this content are \#KPK, \#FraksiPKS, and \#PKS. This content has a duration of 2 minutes 52 seconds. 
Da'wah content in the TikTok account@pksejahtera uses the hashtags \#tausyiah, \#habib, \#Islam, \#pkspelayanrakyat, \#zikir, \#PKS, \#Bertualangrasa, \#tausyiahislam, \#minitausyiah, \#tausyiahhabibsalim, \#ramadhan2021, and \#sykhalijaber. The function of hashtags is to increase visibility and reach so that TikTok users increasingly recognize them. The use of these hashtags shows that the posted content is da'wah content.

\#tausyiah according to the Big Indonesian Dictionary, the definitive word is tausiah, which means message. Still, tausyiah is also interpreted as a religious lecture that contains notes of goodness, justice, and truth. \#habib, according to the Big Indonesian Dictionary, has the Meaning of beloved or lover; it can also mean a call to Arabs which means master, or a call to the one with the title Sayid. According to the Big Indonesian Dictionary, remembrance has the Meaning of praise to Allah, which is said repeatedly. Still, it can also mean prayer or singing praises (performed at the celebration of the Prophet's Birthday), or it can be interpreted as the act of saying remembrance.

\#bertualangrasa, the hashtag adventuring taste, consists of two syllables, namely adventurous and rasa. Adventure in KBBI means wandering everywhere or always going around. While the word fancy in the $\mathrm{KBBI}$ has many meanings, the Meaning is by the context of the content of Pksejatera da'wah, namely the heart's response to something (the senses). So that the Meaning of \#bertualangrasa is an odyssey of the soul towards the teachings of Islam. \#tausyahislam, the hashtag tausyiah Islam consists of two words, namely tausyiah and Islam for the Meaning of these two words has been explained in the Meaning of \#tausyiah and \#Islam. While the Meaning of tausyahislam is a religious lecture containing messages of goodness, justice, and truth in Islam taught by the Prophet Muhammad SAW guided by the holy book of the Koran, which was revealed to the world through the revelation of Allah SWT. \#minitausyiah, this hashtag consists of syllables, namely the word mini and the word tausyiah. According to KBBI, mini means (size) minor, a little, and so on. Mini tausyiah can be interpreted as a religious lecture that contains messages of goodness, justice, and truth in tiny sizes.

According to the Big Indonesian Dictionary (KKBI), Islam means the religion taught by the Prophet Muhammad guided by the holy book of the Koran, which was revealed to the world through the revelation of Allah SWT. \#ramadhan2021 is a combination of the words Ramadhan or Ramadan, which, according to the Big Indonesian Dictionary (KKBI), 
means the 9th month of the Hijri year (29 or 30 days). In this month, Muslims are required to fast. And the year 2021 shows the Christian year where the month of Ramadan takes place. \#pkspelayan Rakyat and \#PKS are hashtags that show that this content is created by the Prosperous Justice Party and shows that PKS as a political party and a da'wah organization is a servant of the people, including when spreading da'wah messages through Tik'Tok accounts.

\#tausyiahhabibsalim and \#syekhalijaber show that this content is a religious lecture where the messenger is a preacher who has the competence of da'wah science so that this da'i is a competent resource for preaching. Two preachers convey da'wah messages on the TikTok pksejahtera account, namely Habib Salim Segaf Aljufri, a cleric and politician. They once served as the 26th Minister of Social Affairs in the era of President Susilo Bambang Yudhoyono. He also served as Ambassador of Saudi Arabia and Oman from December 2005 - 2009. In the Prosperous Justice Party, he served as Chairman of the Sharia Board of the Prosperous Justice Party (PKS). Director of the Sharia Consulting Center and actively teaches at UIN Syarif Hidayatullah, Institute of Islamic Sciences and Arabic Language (LIPIA), and Dirasat Islamiyah Jakarta. An educational history of S1 (1976), S2 (1980), and S3 (1986) in the field of Sharia at the Islamic University of Medina, Saudi Arabia.

The next preacher is Sheikh Ali Jaber, a memorizer of the Koran. Even at the age of 11, he has memorized 30 juz of the Koran. Educational history ibti $\neg$ daiyah (1989), tsa $\neg$ nawiyah (1992), Aliyah (1995). In 1997 mulazamah (melasma) lessons of the Qur'an at the Prophet's Mosque, Medina. The teachers of Sheikh Ali Jaber Sheikh are Abdul Bari's Subaity (Imam of the Prophet's Mosque, previously Imam of the Grand Mosque), Sheikh Khalilul Rahman (Scholar of the Qur'an in Medina and Expert Qiraat), Sheikh Prof. Dr. Abdul Azis Al Qari' (Chairman of the Ulema Council for Printing Al-Qur'an Medina and Imam of the Quba Mosque), Sheikh Said Adam (Chairman of the Management of the Tomb of the Prophet Muhammad and the Key Holder of the Prophet's tomb), Sheikh Muhammad Ramadhan (Chairman of the Tahfidzul Qur'an Council in Prophet's Mosque), and Sheikh Muhammad Husein Al Qari' (Chairman of Qira'at Ulama in Pakistan). On January 14, 2021, Sheikh Ali Jaber died at the age of 44 years.

The da'wah content on the Tik'Tok account @ pksejahtera on January 14, 2021, is themed about death, and the world is not true life. Sheikh Ali 
Jaber delivered this content through his voice recording. This content was created as a form of condolences from PKS for the death of Sheikh Ali Jaber on the same date. This content is 27 seconds long, liked by 112 tiktokers, commented on by three tiktokers, shared 16 times, and viewed 1,682 times.

The content on March 4, 2021, is themed about remembrance as a medicine for the heart because it is too love for the world. Habib Salim Segaf Aljufri delivered this da'wah with a duration of 58 seconds. This content was liked by 1,927 tiktokers, commented on by 20 tiktokers, shared 451 times, and viewed 28,500 times.

Da'wah content on March 7, 2021 has the theme about softening and softening the heart, one indicator that a hard and dirty heart is difficult to cry or shed tears. Habib Salim Segaf Aljufri delivered this da'wah with a duration of 1 minute. This content was liked by 323 tiktokers, commented by four tiktokers, shared 30 times, and viewed 3,143 times.

Da'wah content on March 30, 2021, with the theme about humans having to move to find fortune, including when they want to go to heaven, some efforts are made, Habib Salim Segaf Aljufri delivered this da'wah with a duration of 1 minute. This content was liked by 286 tiktokers, commented by six tiktokers, shared 46 times, and viewed 3074 times.

Da'wah content on the Tik'Tok account @pksejahtera only has four ranges over nine months, starting from September 3, 2020, to June 22, 2021. The Tik'Tok account @pksejahtera has posted about 174 videos. It turns out that the content with the most views is the content about PKS's attitude towards the BKN's national insight test that endangers the nation's future. It was broadcast 736,000 times, liked by 51,800 tiktokers, commented on by 4,810 tiktokers, and shared 7,882 times. The hashtags for this content are \#KPK, \#FraksiPKS, and \#PKS. This content has a duration of 2 minutes 52 seconds. 
Source: Akun TikTok@pksejahtera

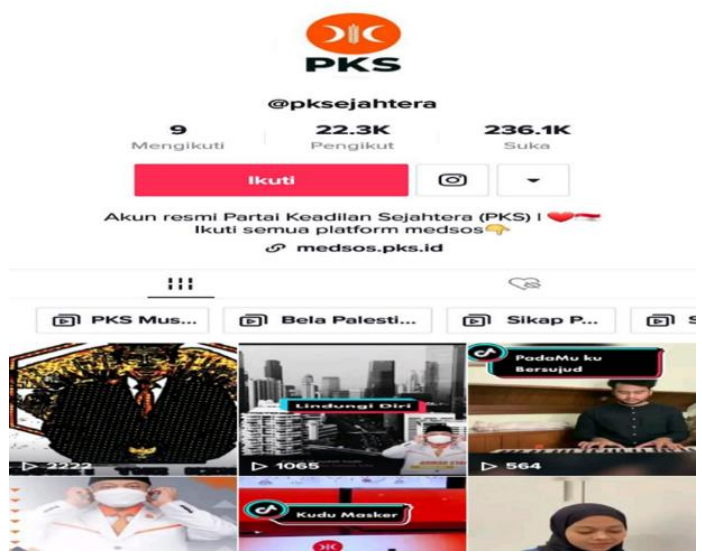

Figure 1. Akun TikTok pksejahtera

\section{Denotative Meaning in pksejahtera's TikTok Account}

Da'wah content on the TikTok account@pksejahtera on January 14, 2021, is themed about death. The video entitled "Dead" is 27 seconds long and contains a da'wah narrative delivered by Sheikh Ali Jaber. This narrative is also made up of text in the video. Here's the narration:

"Death means that life before death is meaningless. Meaningless. This world is not real life. Real-life. After death. And we only die once. Won't die again."

The choice of words conveyed emphasizes death. The word dead is spoken and written four times in this video. At the same time, the word death, which is the theme of this video, is said and registered once. According to the KBBI, the word dead is a verb that means that one has lost his life or is no longer alive. Meanwhile, according to the KBBI, the word death is a noun that means about death.

Video visualizations and descriptions of death depict the forest in a twilight setting as the sun goes down. Describes as if walking on the edge of the forest on a path. The sun is not clear because it is covered by the leaves of the trees that grow in the forest. In addition to the orange trees, on the right side of the road, you can see a lake that reflects the shadows of the trees and also reflects the shadow of a mountain that looks far from the forest-accompanied by a religious song entitled A Confession and sung by a male singer. The verse is sung: "Oh God, I am not an expert in heaven, nor can I withstand the torments of hell.". At the end of this video, it closes with a flayer of condolences from the Prosperous Justice Party for 
the death of Sheikh Ali Jaber on Thursday, January 14, 2021.

This video ends with a mourning flyer for the death of Sheikh Ali Jaber, one of the da'i in Indonesia. The departure of Sheikh Ali Jaber caused a deep sense of sorrow for all circles, including PKS. Sheikh Ali Jaber's ability to get along with all rings without being limited by political views made Sheikh Ali Jaber acceptable to anyone. The behavior of Sheikh Ali Jaber made the deceased one of the role models for mad'u. So it is not surprising that PKS, as one of the political parties, also feels the loss of the death of Sheikh Ali Jaber.

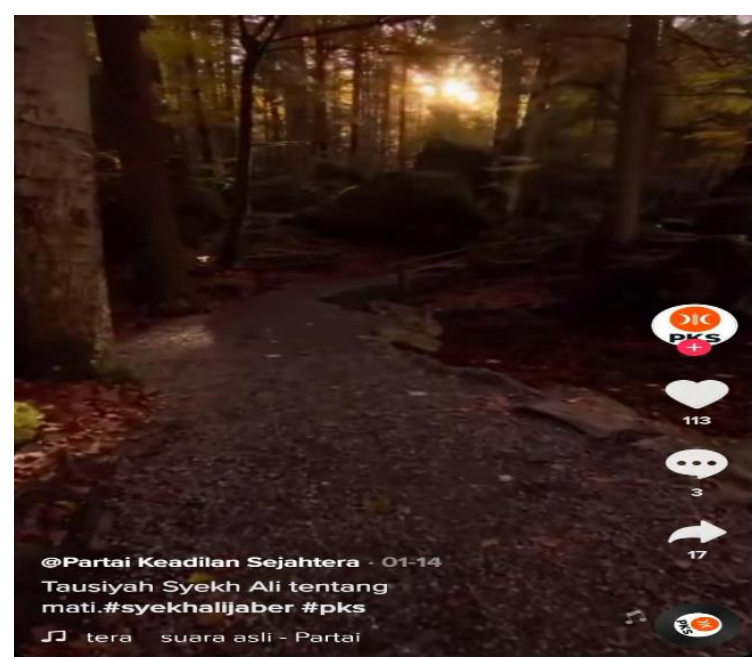

Source: Akun TikTok@pksejahtera

Pigure 2. Twilight scene in the forest. 


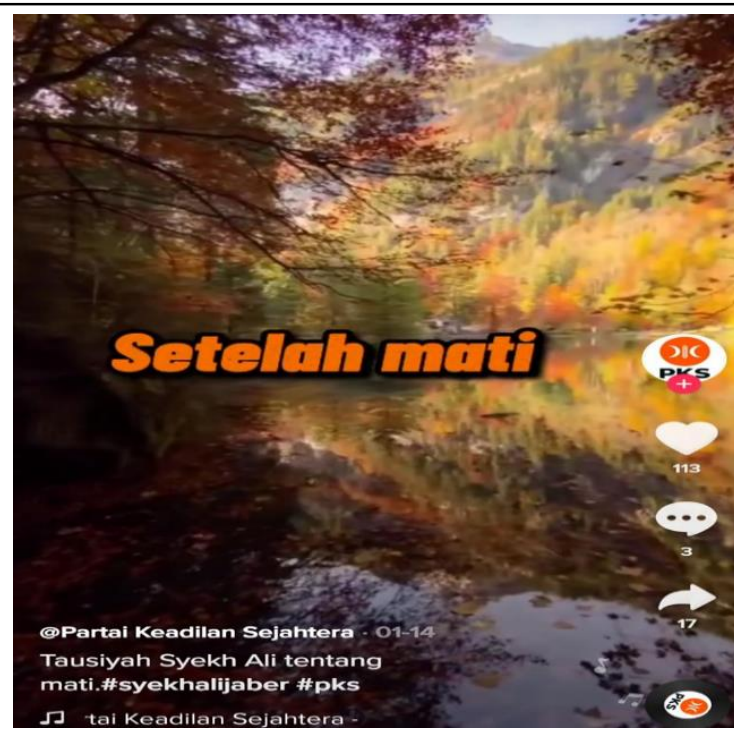

Source: Akun TikTok@pksejahtera

Figure 3. The reflection of the trees on the lake.

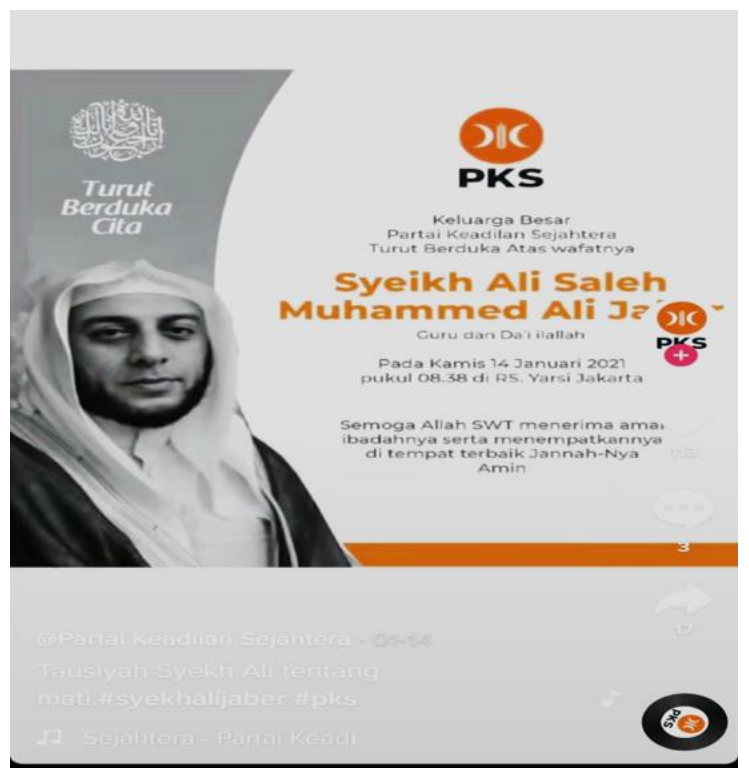

Source: Akun TikTok@pksejahtera

Figure 4. Flayer duka cita. 
The content on March 4, 2021, is themed about remembrance, with the title forcing memory. Habib Salim Segaf Aljufri delivered this da'wah with a duration of 58 seconds. In this video, there is a narration of da'wah. This narrative is also made up of text in the video. Here's the narration:

"If someone is sick, is it good to eat it? not good. Sick him. Just eat it, don't get excited. Likewise, remembrance when someone does dhiker, will not feel the sweetness of the pleasure of remembrance. If it's in his heart, it hurts his heart. World love. Hard heart. Yes, there is no pleasure because it is treated; how to treat it? Yes slowly. Only then did he feel the pleasure, but what is clear is the remembrance itself; in Shaa Allah, even if a doctor always says one's body, even if your body is sick, force yourself to eat! So that's bealthy. So if your body is arrogant, just multiply remembrance!"

The choice of words conveyed emphasizes the remembrance. The word remembrance was spoken by Habib Salim Assegaf Aljufri four times. This word is also written four times in text form. Zikr is a noun which, according to KBBI, has the Meaning of repeated praise to Allah or the act of reciting remembrance. At the same time, the word remembrance is spoken and written once in this video. In KBBI, the word remembrance has the Meaning of saying remembrance; remembering and repeating the name and majesty of Allah; do remembrance.

The visualization and description of remembrance depict the atmosphere on the edge of a barren and dry lake with a slow wind blowing. You can see the visualization of the situation and conditions while camping on the edge of the lake because you can see mats, teapots, and piles of stones from a bonfire. The next scene depicts water gushing from a pipe that continuously releases heavy, clear, and clear water even though the land around it is barren because it is in a construction area. It seems that there is one building that has not been done and is not suitable for occupancy. The last scene depicts a garden where the plants are bearing fruit, and the fruit falls to the ground because the fruit is ripe so that it can fall on its own. This video is accompanied by classical Allegro music. The Social Justice Party logo appears at the end of this video. 


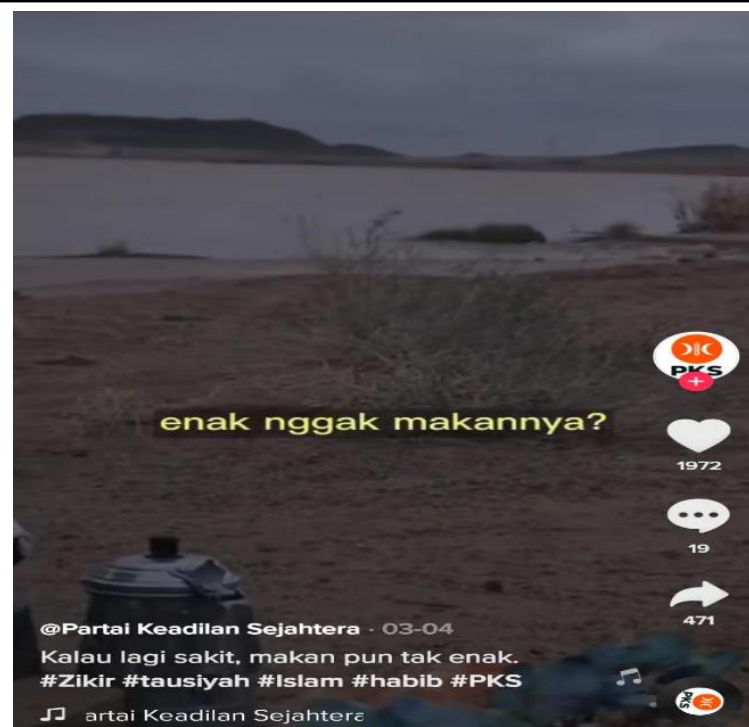

Source: AkunTikTok@pksejahtera

Figure 5. The barren land scene by the lake.

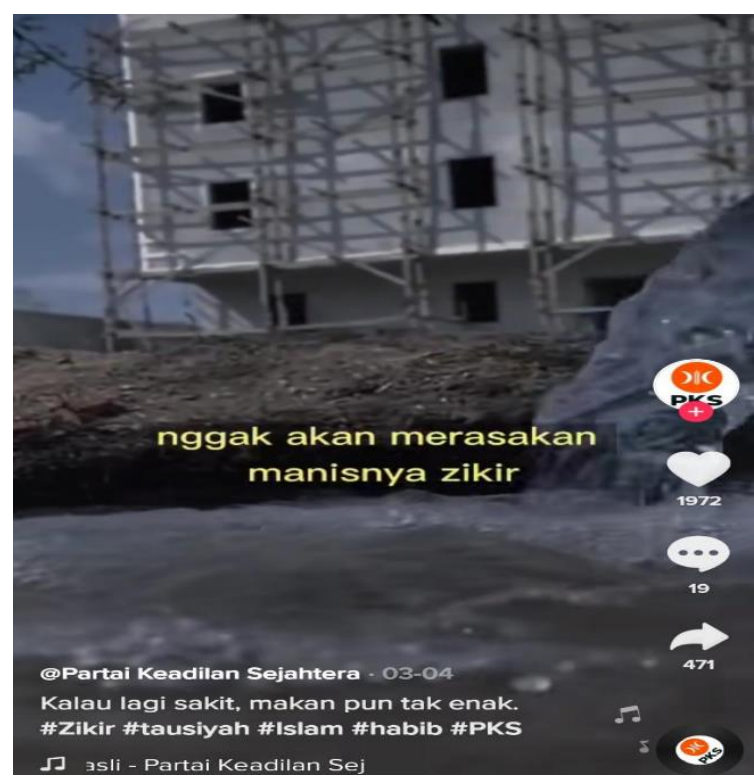

Sumber: Akun TikTok@pksejahtera

Gambar 6. Scene of water flowing in a barren area. 


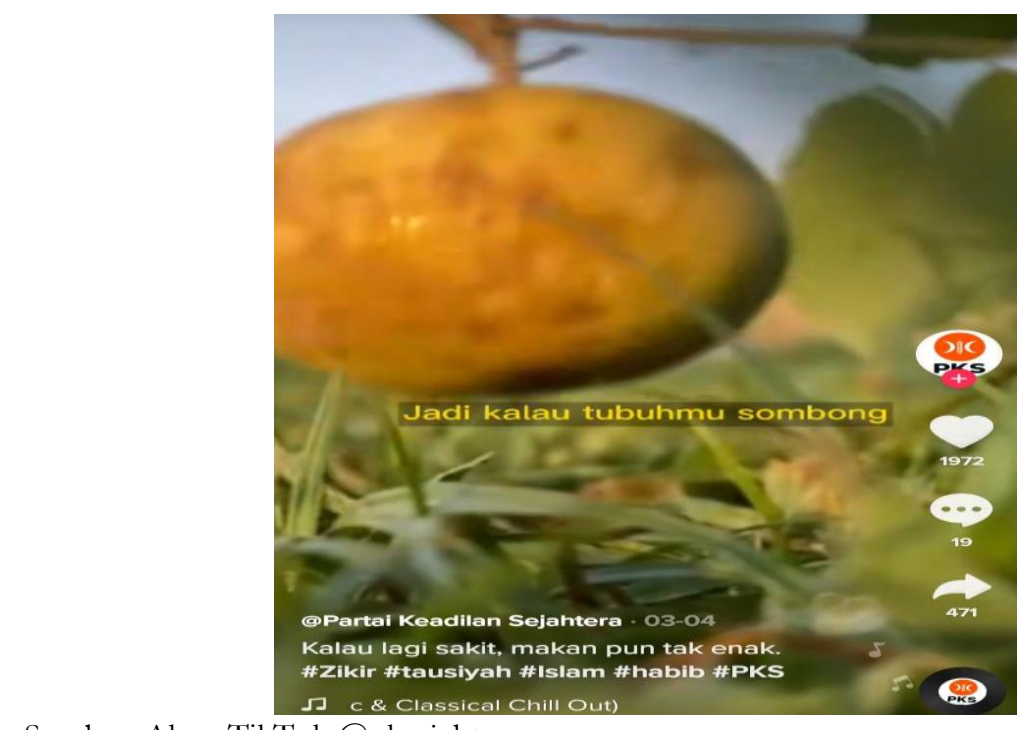

Sumber: Akun TikTok@pksejahtera

Gambar 7. Green and lush garden scene.
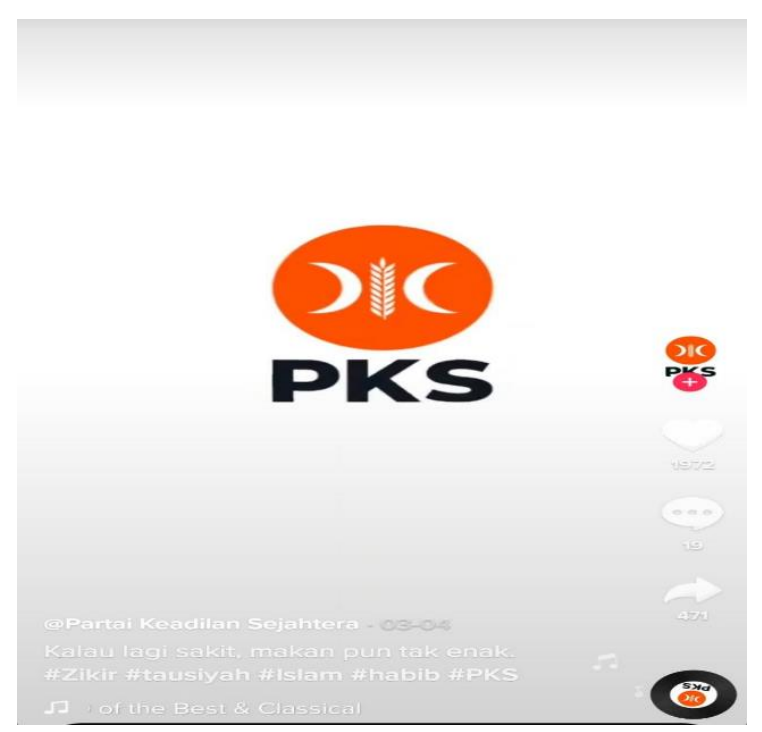

Sumber: Akun TikTok@pksejahtera

Gambar 8. PKS logo as video cover.

The da'wah content on March 7, 2021 is themed about softening and 
softening the heart. The title of this video is if you can't cry. Habib Salim Segaf Aljufri delivered this da'wah with a duration of 1 minute. The narrative of this da'wah content is as follows::

"If people can't cry, where is the problem? The problem is not in his eyes; the problem is in the heart; the problem is in the heart. That's what the heart must be because of those eyes he cries because it has a direct relationship with the heart itself. If the heart is not soft, not soft, there is no way those eyes can cry. How to make you cry: Our scholars give examples of how we want to wear clothes, these clothes are dirty, how, yes ffirst wash the clothes, after that give perfume, then wear. Your heart is like that. So if your eyes can't shed tears, then the attention bere (heart) is not the eyes".

The choice of heart, eyes, and crying is a form of emphasis in the da'wah message in this video. Habib Segaf Aljufri said the conscience four times and the conscience written in the text having the same number. The word heart belongs to a noun. In the KBBI, the word heart has many meanings; one of the meanings that are by the context of this da'wah message is something in the human body that is considered a place for all inner feelings and a place to store understanding (feelings and so on). At the same time, your heart in this content narration is only conveyed once. Your heart is a verb. In KBBI, it means to put one's heart; have mercy (dear and so on).

The word mata in this video is delivered twice. The word eye is a noun. The term look in KBBI has many meanings. The Meaning that best fits this da'wah's message is the sense of seeing; a sense of sight. Meanwhile, the word crying is conveyed four times in the da'wah message about the heart's softening. The word cry is a verb. In KBBI, the word calling means giving birth to feelings of sadness (disappointed, sorry, etc.) by shedding tears and making sounds (sobbing, screaming).

This visualization and description of the video about softening and softening the heart begin with a scene of a boat sailing on the open sea in cloudy weather where clouds cover the sun's rays. On the deck of the ship, there are glasses and glasses in which there is a spoon. The next scene is crying eyes; it looks like tears are falling over the face. Then the scene continues at the washing place; two washing machines are seen washing clothes and then hanging clean garments that have been washed ready to be worn; the following scene switches to the feet of a man who will wear sandals, the man is seen wearing a pair of mountain sandals. While holding sunglasses. The last scene closes with a person holding a piece of glass, and 
then in the middle of the glass there is an image of a red heart shape which then the glass is dropped on a rock so that the glass shatters into pieces. This video is also accompanied by instrumental music.

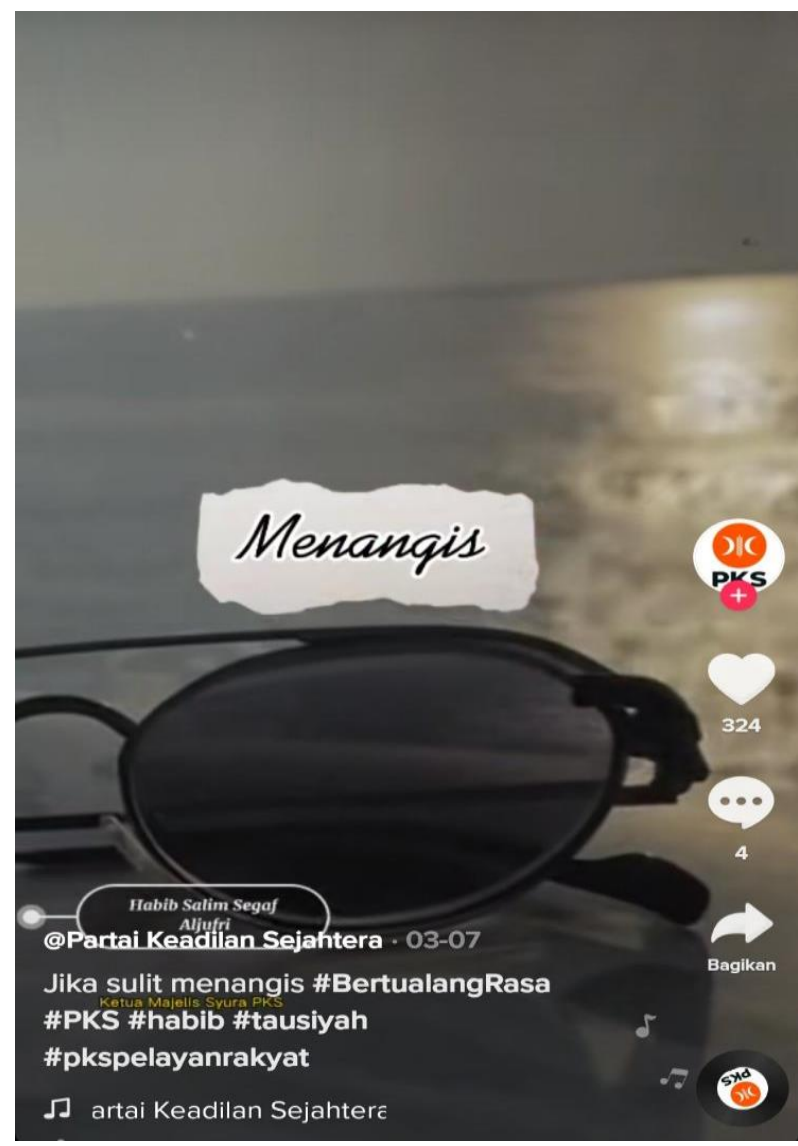

Sumber: Akun TikTok@pksejahtera

Gambar 9. PKS logo as video cover.. 


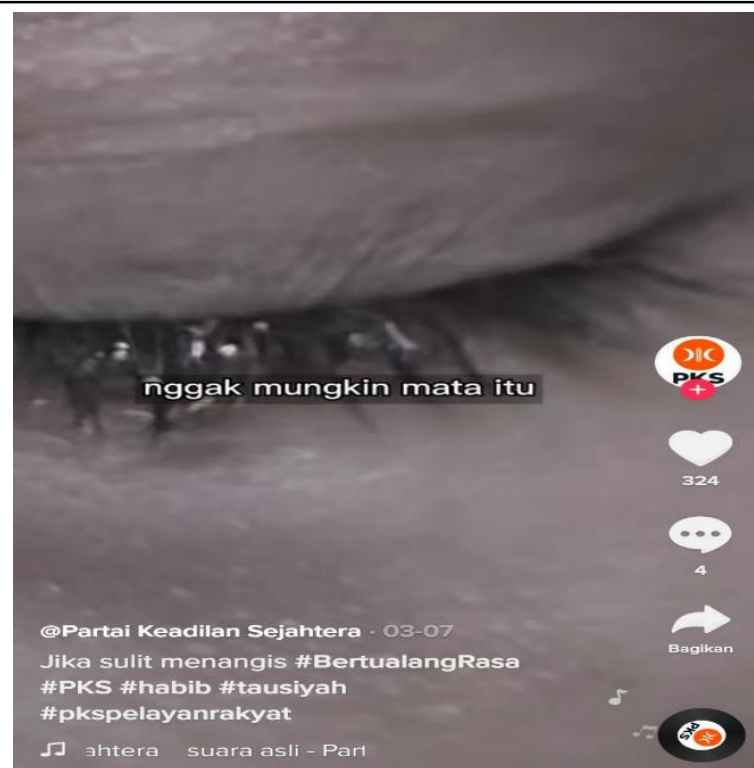

Sumber: Akun TikTok@pksejahtera

Gambar 10. PKS logo as video cover..

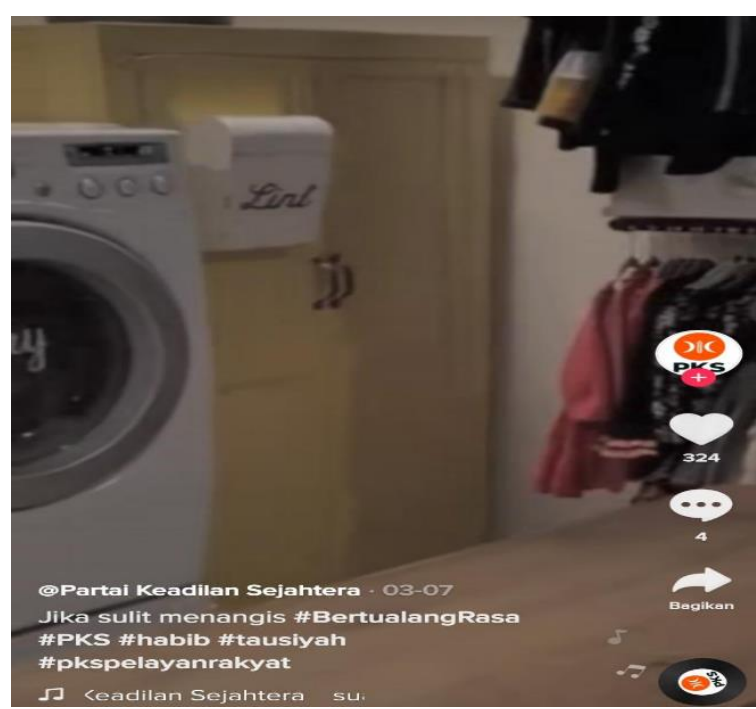

Sumber: Akun TikTok@pksejahtera

Gambar 11. PKS logo as video cover.. 


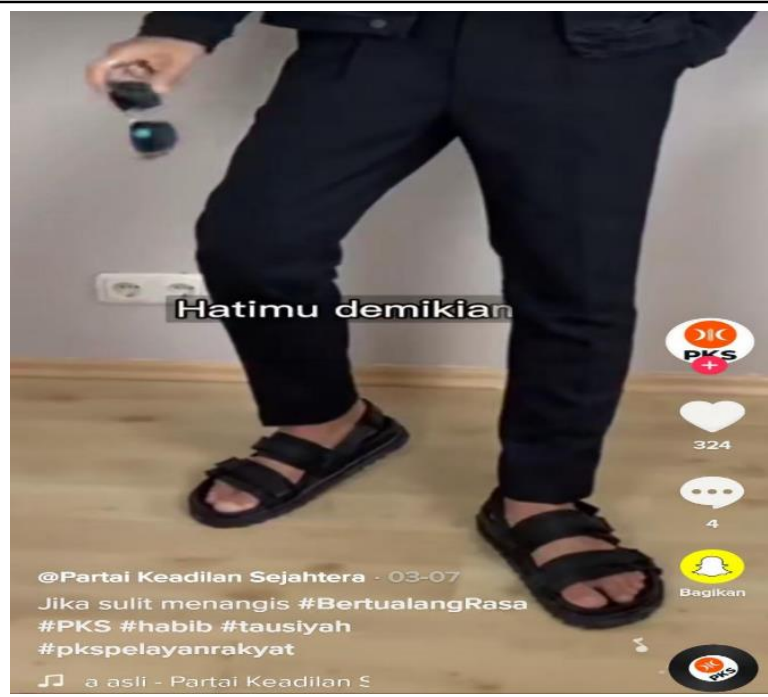

Sumber: AkunTikTok@pksejahtera

Gambar 12. PKS logo as video cover.

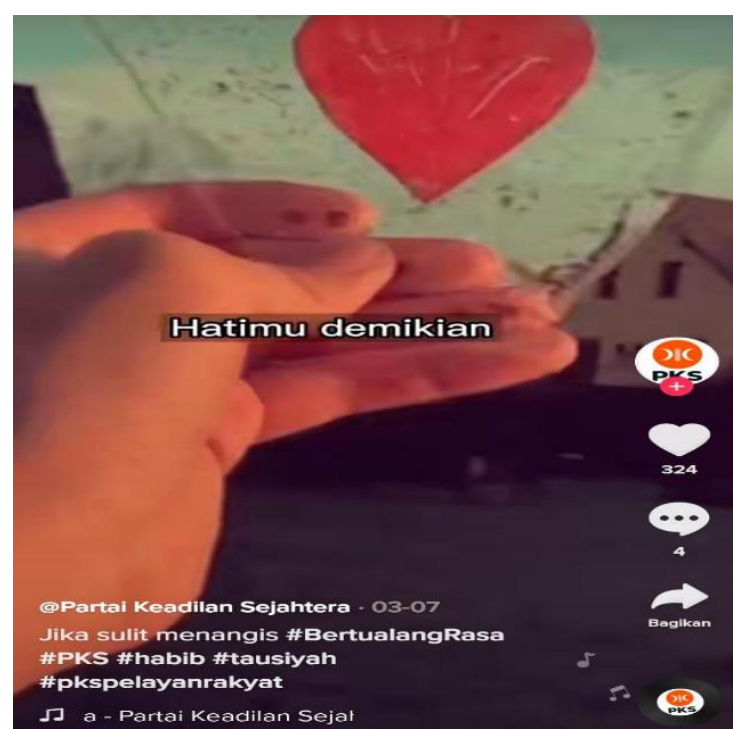

Sumber: Akun TikTok@pksejahtera

Gambar 13. PKS logo as video cover.

The da'wah content on March 30, 2021, is themed about moving to find fortune and worship with the title "must move". Habib Salim Segaf 
Aljufri delivered this da'wah with a duration of 1 minute. The narration of this da'wah video is in the form of text and sound. The da'wah narrative is as follows:

"Wahai si fulan! assama'laa tumthiru dzahaban was laa Siddharth; this sky does not rain gold and silver for you, faidza qudiyatus sholaatu fan tasyiruu fil ardhi, wabtaghu min Fadlallah, if the prayer ends at dawn, fantasyiruu, spread to the earth's land, seek God's gift, God's gift, time to lose to other God's creatures?! Try the birds at night to spend the night, where at dawn? All of them fly on empty stomachs, all of them come home full, so you have to move! So if you want to go to heaven, you have to do good deeds, you have to worship, you have to do this, don't just keep silent, everyone has to move".

The choice of words in the text of this video can be interpreted as a form of emphasis that moves to seek fortune in the context of this world and moves to worship in the context of the hereafter. Must be alone in the $\mathrm{KKBI}$ is an adjective that means appropriate, mandatory, must (may not). The word must be said four times. Meanwhile, the word "don't" is an adjective, which according to the KBBI, has the Meaning of a word declaring a prohibition, meaning no, it should not be necessary. And the word no is said only once.

The visualization and description of this moving video depict the natural atmosphere of the mountains, where there are mountains that look far away. The color of the hills is bluish, with the sky looking blue because the weather is cloudy. There is a stretch of rice fields that look lush with rice color gradations from green to yellow. The hill is green, and several houses are there, indicating this scene is a rural scene at the foot of the mountain. The next scene depicts the sky with the rapid movement of clouds due to cloudy weather. Then the scene switches to a sunset on the beach. The twilight atmosphere with an orange sky is the bias of the evening and the footsteps of drifting clouds. You can see the boundary between the sea and the sky. This scene is played with a fast-motion process (moving fast).

The scene changes from a twilight atmosphere when the sun slowly sinks to a post-sunset atmosphere so that a purple glow appears, which is a faint purple light that is seen when it is a clear day in the western sky. Next is a scene that depicts the morning atmosphere in a building on the top floor, such as a room in an apartment. The sky is clear, with gradations between white and orange. Birds were seen flying hand in hand across the 
sky and clouds. The last scene depicts the atmosphere in front of the golden-domed mosque. There is a garden in the parking lot of the mosque. The shade trees planted in the parking area make the outside of the mosque look beautiful. This video is accompanied by instrumental music.

This video closes with a Ramadan theme flyer from PKS with the motto "The Spirit of Ramadan, The Spirit of Serving" this is an adjustment to the new PKS tagline, namely Together Serving the People. The Ramadhan theme flyer from PKS with the motto Spirit of Ramadan, Spirit of Serving, closes this video. This flyer shows that this video is included in the propaganda content of PKS to fill the month of Ramadan. The PKS logo always appears in every scene as a watermark so that other parties do not claim the content. In addition, the watermark also functions to protect content as a marker of the original work of the creator or content owner; even the watermark can serve as a form of promotion from the content owner in this video, namely PKS.

The firmness of the da'wah message conveyed by Habib Salim Segaf Aljufri can be seen from the text listed in the video with an exclamation mark as a sign of firmness. An exclamation mark is used as a form of expression and a statement in the form of a command. Even this exclamation mark represents earnestness, disbelief, or strong emotion. Question marks are also used in the text of this video as a form of questioning, a form of confirming a statement, even as a form of interaction between the da'i and mad'u.

The text in all videos on this content uses two colors, namely orange and white. Two colors are the two colors used in the latest MCC logo. The head of the Malang City DPRD faction, Trio Agus Purwono, stated that an effortless orange color would be easily recognized and look bright. At the same time, white, according to KKBI, is the primary color. The orange and white color in the color composition for the video is an emphasis on contrasting colors. The background of the video is blue, orange, purple, and white, so the orange and white text will stand out in contrast. 


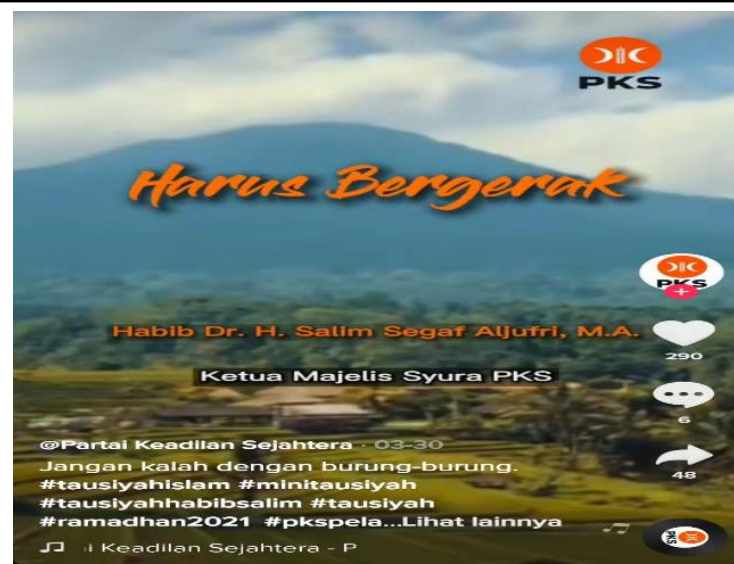

Sumber: Akun TikTok@pksejahtera

Gambar 14. Logo PKS sebagai penutup video

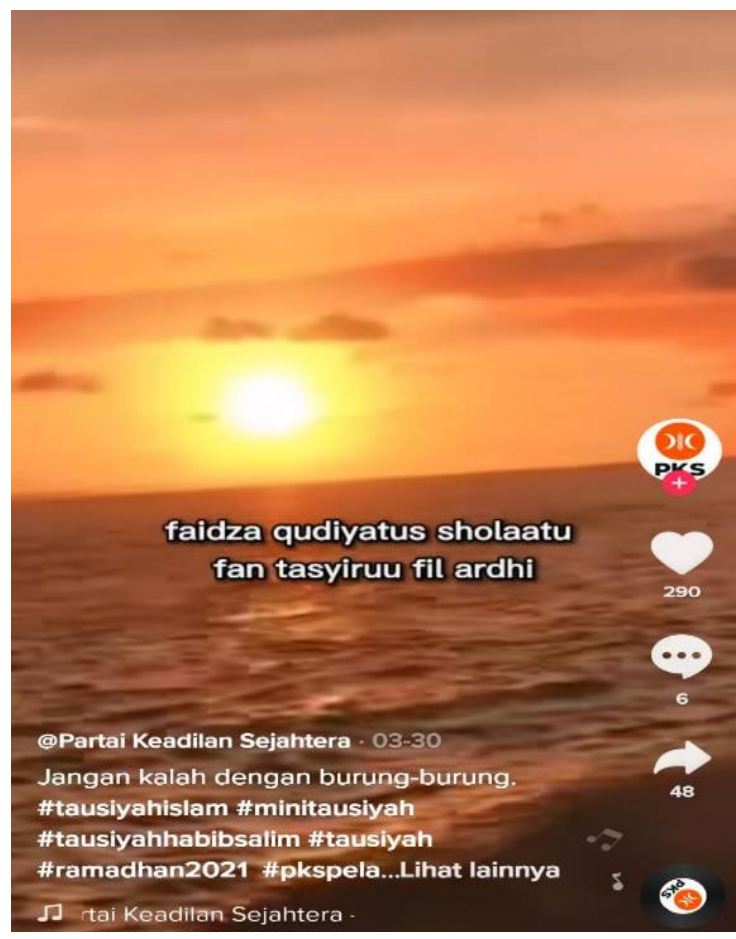

Sumber: Akun TikTok@pksejahtera

Gambar 15. Logo PKS sebagai penutup video. 


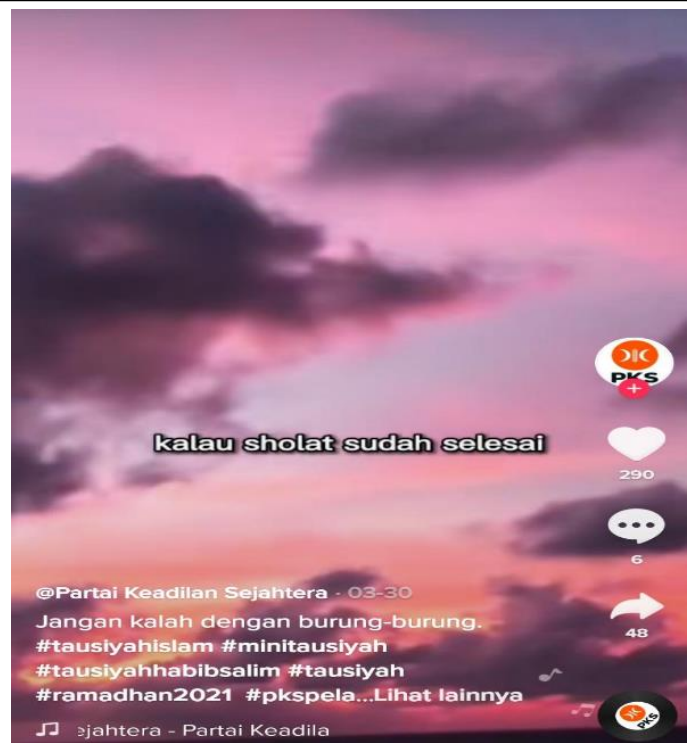

Sumber: Akun TikTok@pksejahtera

Gambar 16. Logo PKS sebagai penutup video

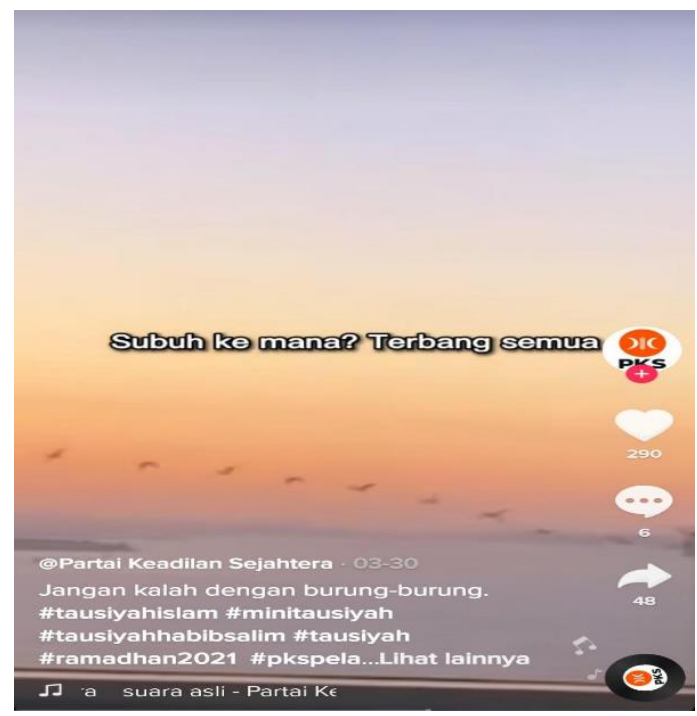

Sumber: Akun TikTok@pksejahtera

Gambar 17. Logo PKS sebagai penutup video 


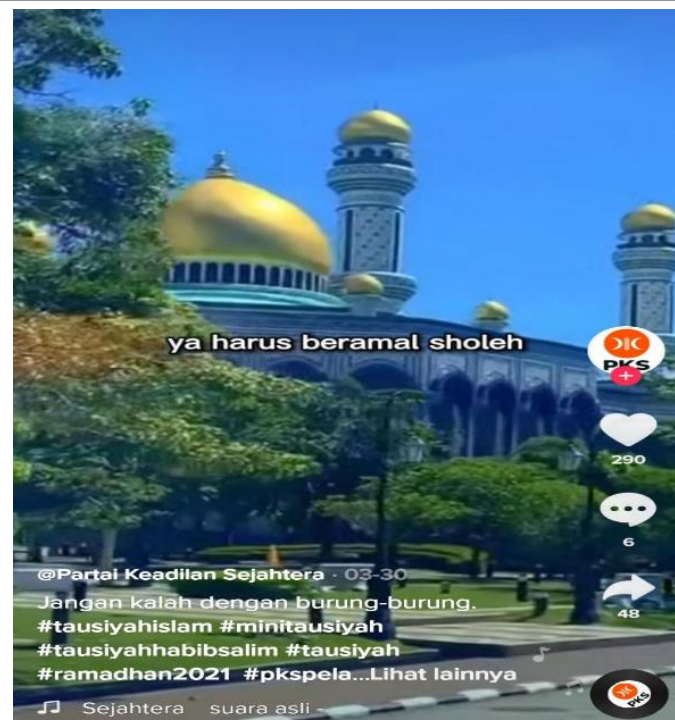

Sumber: Akun TikTok@pksejahtera

Gambar 18. Logo PKS sebagai penutup video

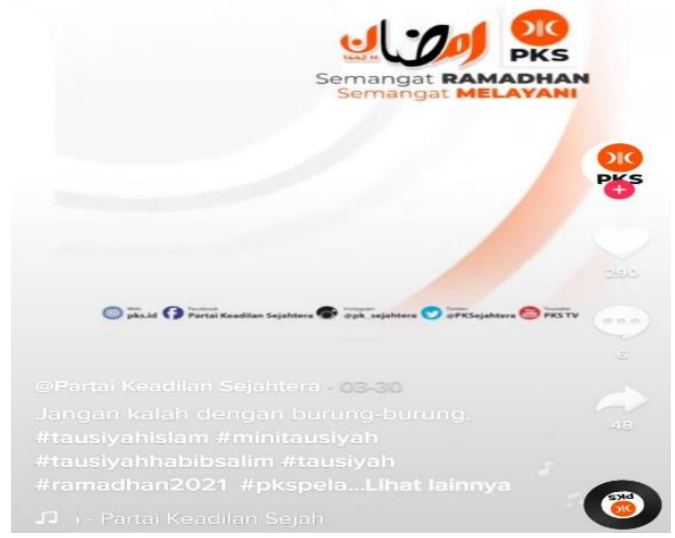

Sumber: Akun TikTok@pksejahtera

Gambar 19. Logo PKS sebagai penutup video. 


\section{Connotative Meaning in pksejahtera's TikTok Account}

Da'wah content on the Tik'Tok pksejahtera account on January 14, 2021, is themed about death. The video titled death is 27 seconds long. The narration in this content was created when Sheikh Ali Jaber had passed away to give a message of da'wah that touched the heart. Da'wah content about death using the voice of a da'i who recently died at a young age will make mad'u who receive this da'wah message more touched. The choice of a religious song entitled Confession to accompany Sheikh Ali Jaber's voice when reading the text gives a strong impression that death can come unexpectedly, especially during a pandemic like today.

The images are shown also add to the impression that death is a journey home. Return to the owner, namely Allah SWT. The twilight atmosphere, the trees, the almost setting sun, the lake with calm water without ripples, and the high mountains that look far away suggest that humans will eventually arrive at the death phase. The atmosphere that is built is peace, silence, and silence that describes death as leaving a world that is bustling, boisterous, and full of deceit. The accompaniment of religious songs further reminds TikTokers to permanently and immediately repent because death will come suddenly with certainty.

The last image of this video is a mourning flyer for the death of Sheikh Ali Jaber. There is a photo of Sheikh Ali Jaber, who looks calm with a gentle gaze on the pilot. The facial expression of Sheikh Ali Jaber gave the impression that the deceased was one of the da'i who was humble and zuhud. The dead has been given the grace to surrender his life and death only for Allah SWT. The end of Sheikh Ali Jaber has given the impression that mad'u has lost a preacher and an exemplary figure in carrying out hablum minn Allah and hablum min annas.

The content on March 4, 2021, is themed about remembrance with the title forcing remembrance. Habib Salim Segaf Aljufri delivered this da'wah with a duration of 58 seconds. The images shown add to the impression that remembrance is a cure for the aridity of the heart. This can be seen from the changes in the depiction of each scene in the video. Camping on the edge of the dry and barren lake, visible from the expanse of land that does not see any green plants. The plants in the arid land were only some grass that had dried up. Then visualize the rushing water that continues to flow and finally a lush garden with plants bearing fruit. Changes in the atmosphere from barren land, rushing water, and gardens 
with green plants and grass show that remembrance is medicine for an arid and empty heart. Classical allegro music accompaniment further reminds TikTokers to permanently and immediately remember as a remedy for an aching heart.

Allegro classical music accompaniment provides a relaxing effect, so it is hoped that when listening to da'wah messages can increase the concentration of thinking from mad'u. Classical music can stimulate cognitive functions, namely observing, memory, concentrating, and planning. The classical music heard by mad'u can activate the brain waves used for thinking and create a relaxing effect so that the brain is ready to learn.

The da'wah content on March 7,2021 is themed about softening and softening the heart. The title of this video is if you can't cry. Habib Salim Segaf Aljufri delivered this da'wah with a duration of 1 minute. The scene shown adds to the impression that crying is a sign of a soft and tender heart. The first scene on the boat gives the appearance of a quiet, calm, but gloomy atmosphere. When the ship moves slowly in seawater that is not choppy but cloudy, the sun shines. Then the scene of crying eyes gives the impression that shedding tears is a sign that the person has a soft and gentle heart.

The scene in the laundry or laundry room where there are two washing machines washing clothes, and then there are lots of clean clothes hanging ready to be worn. This scene gives the impression that if the eyes are difficult to cry, then clean the heart. Difficulty calling is not a problem from the eyes as one of the five senses to see, but the problem is in the heart. A nature that is hard-petrified makes it difficult for the eyes to cry. This soft and gentle heart is needed in all worship, both hablum min Allah and pablum min annas. So for the heart to be quiet and tender, it needs to be cleansed of all kinds of impurities or liver disease.

The scene of wearing mountain boots which are then ready to go, is a scene that gives the impression that a heart that has been cleansed of all kinds of dirt will become a clean, soft, and tender heart so that it is easy to shed tears while worshiping. The last scene closes with a piece of glass with a red heart being thrown to fall on a rock, and then the glass shatters. This indicates that as well as a heart that is easily broken into pieces because of its softness and softness. The accompaniment of instrumental music creates a serene impression that matches the theme of a soft and tender heart. 
On March 30, 2021, the da'wah content is themed about moving to find fortune and worship with the title "must move." Habib Salim Segaf Aljufri delivered this da'wah with a duration of 1 minute. This video showcases the lush nature of the mountains. This indicates that Allah SWT has provided natural resources to be processed by humans to meet the needs of life. Humans must be willing to move (work) because Allah SWT has provided fortune. Fortune will not suddenly come to you if you don't try. Then a sea view from sunrise to sunset. This indicates the passage of time from morning to evening, which is the time for humans to move (work or try) to pick up the fortune that Allah SWT has provided.

The morning atmosphere is depicted in the rooms of an apartment where you can see birds flying across the clouds and sky. This indicates that birds, as living creatures created by Allah SWT, who has guaranteed their fortune, keep moving (trying) to get food. So humans who Allah SW'T gives reason must drive, don't just wait for luck to come. The following scene changes to a magnificent mosque building with a mosque dome. This scene conveys the message if you want to enter heaven, then worship. It is not guaranteed to go to heaven if you stay silent without trying. At the same time, the instrumental music accompaniment indicates that this video hopes that the mad'u who listen to the video will feel calm and comfortable - the power of brain concentration increases when storing, receiving, and responding to this da'wah message.

The text in all videos on this content uses two colors, namely orange and white. The color white psychologically has the Meaning of depicting purity, peace, emptiness, and innocence. White can symbolize new beginnings and give an effect that makes the space feel bigger and broader. At the same time, the color orange has Meaning of strong, warm, full of ambition, energetic, friendly, friendly, adventurous, optimistic, confident. Orange is a combination of red and yellow.

\section{The Meaning of Myths in pksejahtera's TikTok Account}

Sheikh Ali Jaber's voice in reading the narration in the da'wah content about death sounded soft and polite because the tempo of the vote was low with a low tone. When conveying a message about death, the weak and slow speech will give the impression of sadness when honey's ears receive it. Sheikh Ali Jaber delivered da'wah's message in short sentences, low intonation, and slowly with a clear articulation. Syekh Ali Jaber's appreciation when delivering this da'wah message about death gives the 
impression that death, according to Sheikh Ali Jaber's perception, is something that every living being will face. In delivering this da'wah message, several times Sheikh Ali Jaber was heard silent. This is done to give a pause as an effort so that mad'u can think and reflect. This is a dramatic effect so that the message conveyed will be a strong message and be remembered by mad'u.

Habib Salim Assegaf Aljufri delivered the message of da'wah with short sentences, relatively fast and high intonation, with articulations that were sometimes not very clear. This unclear articulation was heard when Habib Salim Asegaf Aljufri mentioned a few words. There is a pause by sounding the letter before saying the word in question. Faint expression when saying how many words will give the impression for mad'u who listen to da'wah content, that Habib Salim Segaf Aljufri is in a hurry or not in a calm state when giving tausyiah. Even the narration that is read with the text listed in this video is sometimes not appropriate. The delivery of da'wah carried out by Habib Salim Segaf Aljufri sounded firm. This is an effort to show that this da'wah message is essential to be heard by mad'u. Habib Salim Segaf Aljufri's intonation is not monotonous but varied. This indicates that Habib Salim Segaf Aljufri delivered da'wah with enthusiasm.

The content on March 4, 2021, is themed about remembrance, with the title forcing memory. Habib Salim Segaf Aljufri's voice sounded relatively fast and firm. There is some emphasis on intonation when conveying specific texts. The focus of this intonation is heard when saying, "it must not be good, it hurts", "heartache", "love of the world, hard heart." Emphasis on intonation and voice that sounds firm will give the impression to mad'u that this message is essential to remember and absorb the implied Meaning of da'wah about remembrance.

The da'wah content video on March 7, 2021 is themed about softening and softening the heart. Habib Salim Segaf Aljufri's voice was heard with a fast tempo and a high tone to seem firm. There is some emphasis on high-pitched intonation when conveying specific texts. The focus of this intonation is heard "when people can't cry," "problems in the heart," "with the heart itself," "the eyes can't be," "yes, wash the clothes first." Emphasis on intonation and a firm voice will make the impression that this message is essential to remember and absorb the implied Meaning of da'wah about softening and softening the heart.

The da'wah content video on March 30, 2021, with the theme about moving to find fortune and worship with the title "must move." Habib 
Salim Segaf Aljufri's voice sounded relatively fast and firm. There is some emphasis on intonation when conveying specific texts. The focus of this intonation is heard when pronouncing: "fantasyiruu," "search," "lost time...", "where did you go at dawn ...", "everyone goes home, full," "yes, you have to...". The emphasis on the intonation and the sound that sounds firm gives the impression to mad'u that this message is essential to remember and absorb the implied Meaning of da'wah about continuing to move to worship.

\section{CONCLUSION}

The Prosperous Justice Party's digital da'wah is a form of PKS as a political party based on Islam that can spread the values of goodness, justice, and truth through da'wah. Da'wah to political parties can be done by adopting these values in the political process of the nation and state. The content on the TikTok@pksejahtera account can be divided into two categories: da'wah content in the form of tausyiah using hashtags, which give the Meaning that the content is indeed created convey da'i messages from da'i to mad'u. Some contents contain statements of goodness, justice, and truth that are universal.

The use of hashtags on da'wah content is an effort to facilitate the search for mad'u who want to find videos containing da'wah messages. These hashtags are adapted to the theme of the da'wah content in the @pksejatera account. The theme of death, remembrance as a medicine for the heart, crying is evidence of a soft and gentle soul, then about the obligation to move to pick up a fortune.

The content of this da'wah can be observed in denotative Meaning, connotative Meaning, and mythical Meaning. The denotative Meaning is the most easily observed Meaning in the da'wah content on the TikTok @ pksejahtera account. Starting from the choice of words, the arrangement of sentences, and even the colors used in the text can be analyzed semiotically. The connotative meaning of da'wah content on the TikTok @pksejahtera account can be observed by selecting image scenes displayed in the mountains, beaches, gardens, seas, birds, and signs that can be scanned and analyzed in denotative meanings to strengthen the message of da'wah.

The Meaning of myth can be observed from nonverbal communication. The Meaning of myth in this da'wah's content follows the nonverbal communication of two preachers, namely Sheikh Ali Jaber and 
Habib Salim Segaf Aljufri. The delivery of da'wah observed from the two preachers is intonation and articulation. Intonation relates to the tone and tempo when Sheikh Ali Jaber and Habib Salim Segaf Aljufri deliver da'wah according to the theme. At the same time, articulation is related to the ability of the two preachers to pronounce consonants and vowels clearly and precisely to minimize misinterpretations when mad'u receive da'wah messages.

The selection of da'i, taking pictures, and compiling sentences in the da'wah video on the content on the@pksejahtera TikTok account are things that strengthen the da'wah message conveyed to mad'u. However, content with the theme of da'wah with the hashtag tausyiah has not become content often broadcast by the TikTok account@pksejahtera. If it is managed thoughtfully, it will be of more value for this Tik'Tok account. Changes to the PKS logo aimed at attracting voters from the millennial and female groups. These two groups can be targeted by utilizing da'wah content on the TikTok @ pksejahtera account. The selection of a da'wah theme by the two PKS target groups will strengthen PKS's branding as a da'wah party.

\section{REFERENCES}

Achmad, A. (1985). Dakwah Islam dan Perubahan Sosial. Yogyakarta: PLP2M. Amin, SM. (2008). Rekontruksi Pemikiran Dakwah Islam. Jakarta: Amzah.

An-Nabiry, FB. (2008) Meniti Jalan Dakwah. Jakarta: Amzah

Arifin, M. (2015) Psikologi Dakwah Suatu Pengantar Studi. Jakarta: Bumi Aksara.

Asroni, A., Yusup, M., \&. Sofia, A. (2013). Dakwah dan Politik: Menakar Konstribusi Organisasi Islam Sayap Partai Politik Bagi Masyarakat Muslim Yogyakarta. Jurnal Dakwah. 14 (1).

Astuty, A. Karim, A. Nurliah. 2019. Analisis Semiotika Komunikasi Visual Melalui "Instagram" Dalam Gambar Postingan Akun @BANTU_DAKWAH. eJournal Ilmu Komunikasi, 7 (4)

Daulay, H. 2020. Dinamika Dakwah Dan Politik Islam Di Malaysia (Kajian Manajemen Dakwah dan Politik Partai Islam PAS). Tadbir: Jurnal Manajemen Dakwah. 2 (1).

Departemen Pendidikan Nasional. (2014) Kamus Besar Bahasa Indonesia. Cetakan ke delapan Belas Edisi IV. Jakarta: Gramedia Pustaka Utama. Detikcom. (2021). Kronologi 2 Pasien Pertama Virus Corona COVID-19 di Indonesia. Diakses 16 Juni 2021, dari 
https://health.detik.com/berita-detikhealth/d4922758/kronologi-

2-pasien-pertama-virus-corona-covid-19-di-indonesia

Effendy, O.U. (2008) Dinamika Komunikasi. Bandung: Remaja Rosdakarya. Enjang., \& Tajiri, H. (2009) Etika Dakwah: Panduan Para Juru Dakwah: (Suatu Pendekatan Teoritik Dan Aplikatif). Bandung: Widya Padjadjaran.

Fackhruroji, M. (2010). Dakwah Islam dan Inovasi Media: Peluang dan Ancaman Media Global Atas Dakwah Islam. Jurnal Komunika. 4 (1).

Fakhruroji, M. (2017). Model-Model Dakwah di Era Kontemporer. Mataram: LP2M UIN Mataram.

Ismail, I. (2018) The True da'wa: Menggagas Paradigma Baru Dakwah Era Milenia. Jakarta: Prenada Media.

Khaer, A. 2014. Dakwah Manifesto Masyarakat Madani Partai Politik: Studi Kasus Partai Gerindra. At-Turas: Jurnal Studi Keislaman, 1 (2).

KKBI.com (2012). Kamus versi online/daring (dalam jaringan). Diakses 20 Juni 2021 dari https:/ /kbbi.web.id/denotasi

Kompas.com. (2008). Jumlah Pengguna Aktif Bulanan Tik'Tok Terungkap. Diakses $20 \quad$ Juni 2021, dari https://tekno.kompas.com/read/2021/04/19/14020037/jumlahpengguna-aktif-bulanan-tiktok-terungkap

Kumparan.com. (2021). TikTok Jadi Tempat Saling Berbagi Ilmu dan Menginspirasi. Diakses 20 Juni 2021, dari https:/ / kumparan.com/beritabojonegoro/tiktok-jadi-tempatsaling-berbagi-ilmu-dan-menginspirasi-1uRrwit57eS/ full

Kumparan.com. (2020). Munas, PKS Luncurkan Logo dan Tagline Baru. Diakses 20 Juni 2021. https://kumparan.com/tugumalang/munaspks-luncurkan-logo-dan-tagline-baru-1ugS0nEQpSQ

Kusuma, BMA. Octastefani, T. (2017). Negosiasi Dakwah Dan Politik Praktis: Membaca Orientasi Organisasi Sayap Keagamaan Islam Pada Partai Nasionalis. Al-Balagh: Jurnal Dakwah dan Komunikasi, 2 (1).

Lestari, P.P. (2020). Dakwah Digital Untuk Generasi Milenial. Jurnal Dakwah. 21 (1).

Marlina. (2020). Pemanfaatan Sosial Media Sebagai Media Dakwah Pada Masa Pandemi Covid-19. Jurnal Qaulan, 1 (2).

Mufid, M. Herlina. (2019). Analisis Hermeneutika-Semiotik Terhadap Kajian Keislaman di Media Sosial. Jurnal Kordinat, 18 (2).

Munawwir, AW. (1984) Kamus Al-Munawwir. Yogyakarta: Pustaka Progresif. Natsir, M. Fiqhud Dakwah. (1978) Jakarta: Dewan Dakwah Islamiyah Partai Keadilan Sejahtera.id. (2021). AD ART PKS, diakses 15 Juni 2021, 
dari https://pks.id/file/ad-art-pks

Putri, KMK. Unde, AA. Nadjib, Muhammad. 2015. Semiotika Pesan Instagram Ani Yudhyono Dalam Perspektif Etika Komunikasi. Jurnal $\operatorname{KAREB} A, 4$ (1).

Rahmat, J. (2010) Retorika Modern. Bandung: Remaja Rosdakarya.

Rebuplika.co.id. (2018). Berkelindan Dengan Dakwah Digital. Diakses 15 Juni $2021 \quad$ dari https://www.republika.co.id/berita/qlvtur318/berkelindan

Sayang, AG. Rahardjo, T. (2018). Perilaku Humblebrag Sebagai Penyajian Diri Di Media Sosial Instagram (Studi Semiotika Pada Akun Media Sosial Instagram), Jurnal Interaksi Online. 6 (4).

Setyowati, S. Cahya, A. (2020). Peran Dakwah Daring Untuk Menjaga Solidaritas Sosial Di Masa Pandemi Covid 19. Jurnal Academica, 4 (2). Sobur, A. (2004) Semiotika Komunikasi. Bandung: Remaja Rosda Karya.

Sukirman. (2018) Seri Pendidikan Orang Tua: Mendidik Anak di Era Digital (Edisi Revisi). Jakarta: Direktorat Pembinaan Pendidikan Keluarga Direktorat Jendral Pendidikan Anak Usia Dini dan Pendidikan Masyarakat Kementerian Pendidikan dan Kebudayaan.

Tajiri, H. (2015) Etika dan Estetika Dakwah (Perspektif Teologis, Filosofis dan Praktis). Bandung: Simbiosa Rekatama Media.

Tempo.com. (2008). Jumlah Terbanyak Pengunduh Aplikasi TikTok di Dunia. Diakses $20 \quad$ Juni 2021, dari https://data.tempo.co/data/766/jumlah-terbanyak-pengunduhaplikasi-tiktok-di-dunia

Tubbs, S.L., \& Moss, S. (1996) Human Communication; penerjemah, Deddy Mulyana, Gembirasari. Bandung: Remaja Rosdakarya.

Ujang, S. Mukarom, Z. Sadiah, D. (2018). Perencanaan Dakwah Partai Politik Islam. Tadbir: Jurnal Manajemen Dakwah, 3 (1).

Umar, AM. (2008) Mu jam al-Lughah al-Arabiyah al- Muashirah. Mesir: Alamul Kutub.

Wahid, N. (2019). Jejak Dakwah Partai Keadilan Sejahter (PKS) Memasuki Muhamadyah: Mencermati Kasus di Yogyakarta sebagai Fenomena Politik Dakwah, Jurnal Sosiologi Agama, 13 (2).

William, F. Rice, RE. Rogers, EM. (1988) Research Methods and The New Media. New York. Free Press. 